ROCZNIKI KULTUROZNAWCZE

Tom/Vol. XII, numer/number $2-2021$

DOI: http://doi.org/10.18290/rkult21122-6

PIOTR T. NOWAKOWSKI

\title{
CRACKS IN EDUCATION: ALTERNATIVE SCHOOLING IN CULTIC GROUPS
}

School is a unique place where the verbal transfer of knowledge to the young generation takes place, starting from learning to read and write, through shaping cultural competences, and ending with all the matters that make up the cognitive process. The education system is also responsible for upbringing, understood as supporting a young person in their development towards full emotional, intellectual, spiritual, and social maturity, creating conditions for the development of students' interests and talents by organising extracurricular and non-school activities and shaping social activity and the ability to spend free time. Thus, the school completes the task of socialising, undertaken by the family unit. ${ }^{1}$ The education law of many countries allows non-public entities to establish and run schools, but also permits home education, i.e., teaching children and adolescents by their parents or tutors, taking place at home or places other than school. ${ }^{2}$ Such legal possibilities in the field of organizing education are used by various provenances of cult-like groups. This lets them avoid the uncomfortable situation where children from those communities "have to learn to balance a double standard of values, mores, and beliefs in order to function in both segments of their lives."

Dr. hab. Piotr T. NowAKowsKi - Associate Professor at University of Rzeszów, Head of the Department of Social Pedagogy, Institute of Pedagogy; e-mail: ptnowakowski@ur.edu.pl; ORCID: https://orcid.org/0000-0003-1578-6707.

${ }^{1}$ See more in Bogdan WIĘCKIEWICZ, "Rodzice i szkoła wobec edukacji dzieci w wieku sześciu lat," in Rodzina polska - nowe wyzwania. Wybrane aspekty, ed. Bogdan Więckiewicz (Stalowa Wola: Wydział Zamiejscowy Nauk o Społeczeństwie KUL w Stalowej Woli, 2013), 14-50.

${ }^{2}$ U.K. Department for Children, Schools and Families, Elective Home Education: Guidelines for Local Authorities (2007), 8, http://dera.ioe.ac.uk/6890/3/7373-DCSF-Elective $\% 20$ Ho me\%20Education.pdf.

${ }^{3}$ Janja LALICH and Madeleine TOBIAS, Take Back Your Life: Recovering from Cults and Abusive Relationships (Berkeley: Bay Tree Publishing, 2006), 245. 
Cults differ from other environments in terms of religious, philosophical or cultural beliefs and norms, taking a controversial position on social issues, and as a result they are unable to shape the attitude of responsible citizens in their followers. ${ }^{4}$ The tendency to dichotomize the image of the world resulting from the belief system creates and deepens the separatist approach of cult followers towards the environment. This tendency should be considered a typical feature of every cultic group. When we take into account even the most extensive and complex doctrines of such communities, we find in them an oversimplified picture of reality: white and black, good against evil, spiritual values against material ones, us against them. ${ }^{5}$ The division between sacrum and profanum present inside a sound religious environment, is transformed in the case of a cultic group into a division between the cult members "belonging to the sacrum" and the other part of the society that "lives in profanum." A cult emphasises its separateness, even uniqueness, often describing people from outside its own group in its typical nomenclature as "materialists," "systemites" or "unopened." The cult's doctrine favours the development of an asocial attitude in followers, expressed in simple isolation from social life, which can be harmful especially for themselves (but in a sense also for society, as it bears some consequences of the lack of commitment of these people to the so-called common good), or an antisocial attitude manifested by hostility towards the world situated "on the other side of the barricade." In this way, the cultic group is responsible for the social confusion of its followers. $^{8}$

\footnotetext{
${ }^{4}$ Often limiting themselves to accommodating the objections of their followers regarding the contemporary culture of the West, which is undergoing a crisis, as pointed out by Robert T. PTASZEK, "Filozoficzno-kulturowe uwarunkowania działalności współczesnych grup kultowych," in Grupy kultowe: uwarunkowania społeczne, ed. Mariusz Gajewski (Kraków: WAM, 2012), 425.

${ }^{5}$ Steven Hassan, Combating Cult Mind Control (Newton: Freedom of Mind Press, 2018), 140; see also Michael Kropveld and Marie-Andrée Pelland, The Cult Phenomenon: How Groups Function, transl. Natasha DeCruz and Gwendolyn Schulman ([Montreal]: Info-Cult, 2006), 56.

${ }^{6}$ Piotr T. Nowakowski, Sekty: co każdy powinien wiedzieć (Tychy: Maternus Media, 1999), 118.

${ }^{7}$ Including destructive cults which "do not allow their followers to communicate with outsiders, and in the end, the leaders influence their followers to get involved in destructive activities such as killing, murder, and mass suicide," write Raymund T. PALAYON, Richard Watson TodD, and Sompatu Vungthong in their "The Language of Destructive Cults: Keyness Analyses of Sermons," Communication \& Language at Work 7, no. 1 (2020): 43.

${ }^{8}$ Piotr T. NOWAKOWSKI, "Uzasadnienie ujęcia problemu sekt na gruncie pedagogiki resocjalizacyjnej," in Sekty jako problem współczesności, ed. Piotr T. Nowakowski (Mysłowice: Górnośląska Wyższa Szkoła Pedagogiczna imienia Kardynała Augusta Hlonda, 2008), 186-87.
} 
This break-up with general social values may - as we mentioned-be expressed in the establishment and running the cults' own educational institutions or in the implementation of home education, which in extreme cases may be associated with the most ordinary refusal to send children to school, which - in the context of the principle of compulsory education - can be equivalent to breaking the national law.

\section{ESTABLISHING OWN EDUCATIONAL INSTITUTIONS}

The noticeable tendency of cults to limit the contact of its followers with people "from the outside" is reflected in its critical attitude to the common school system and formal education, ${ }^{9}$ and therefore in establishing own schools, where the education formula is different from that found in traditional educational institutions.

The International Sahaja Public School can serve as an example. It is located at the foot of the Himalayas, approximately $10 \mathrm{~km}$ from the village of Dharamshala in northern India, established in 1990 by the Sahaja Yoga movement. ${ }^{10}$ The facility is isolated, attended by the children of the followers from many countries around the world. As Judith Coney writes, the school accepts pupils from the age of four, in which case "often very young children are separated from their natural parents for prolonged periods, as they usually stay in India for nine months, returning home for the other three months of the year." 11 The operation of the facility has often caused controversy. In Western Europe, there were cases of suspending the right of custody of a child for parents who sent their children to this school. This was the case in Austria, for example, as mentioned by Brigitte Schinkele cited in Eva M. Synek: "the mother's guardianship was partly substituted (after legal intervention of the grandmother), as she was not willing to take her boy out of a Sahaja Yoga boarding-school in India in order to grant schooling in Austria." ${ }^{12}$ On the other hand, in France, the court of appeal allowed the mother to keep custody of the

\footnotetext{
${ }^{9}$ Margaret T. Singer, Cults in Our Midst (San Francisco: Jossey-Bass Publishers, 2003), 250.

${ }^{10}$ Sahaja Yoga was founded in 1970 by Shri Mataji Nirmala Devi (1923-2011), more widely known as Her Holiness Shri Mataji Nirmala Devi or as "Mother" by her followers.

${ }^{11}$ Judith Coney, Sahaja Yoga: Socializing Processes in a South Asian New Religious Movement (Richmond: Curzon Press, 1999), 159.

${ }^{12}$ Eva M. SYNEK, "The Limits of Religious Tolerance - A European Perspective," Journal for the Study of Religions and Ideologies 1, no. 3 (2002): 50.
} 
children, provided that she did not send any of them to the school in question. This also followed the intervention of the children's grandmother. The court justified its judgement stating that "the quality of the teaching is no way guaranteed,... the child's schooling and professional future is completely uncertain,... he would for a very long time be in a situation of geographical and psychological isolation, without any real contact with the outside world, and... his young age and the absence of other references, would be completely incapable of refuting this situation." The judge concluded: "His mental health is in danger and his conditions of education very severely compromised." 13

Even more notoriety was achieved by schools run by the International Society for Krishna Consciousness (ISKCON). ${ }^{14}$ When the American ashrams of the movement began to mature, a decision was made to create special institutions to provide children with proper education. The founder of the organization, Swami Prabhupada, pointed out that believers should be free to distribute religious books and do other work for the community. Hence, children should be sent to boarding schools so that they are not dependent on their parents and, at the same time, can be educated as devoted students. As a result, by the end of the 1970s several such schools had been established, specified as gurukulas (Sanskrit guru for 'teacher' or 'master'; kula 'family' or 'home'), often run by untrained and inexperienced staff. After more than a decade, there have been rumors and even complaints of physical and sexual abuse in these facilities. The teachers and other staff, who were given this segment of duties mostly because they were judged to be incompetent with recruiting new followers and in trading activities, had created a culture of abuse. A twelve-year-old student later confessed that all of his classmates had the same prayer: "Krishna, get me the hell out of here." Eventually, in October 1998, the movement leaders publicly admitted that some children had been sexually abused, beaten, and locked in wardrobes infested with cockroaches. Some of them were as young as three years of age. In 2000, a court case was initiated and Windle Turley, the prosecuting attorney, described the practice as "the most unthinkable abuse and maltreatment of little children we have ever seen." As a result of the lost court case, more than ten Hare Krishna temples went bankrupt in the process to satisfy the claims under the adjudged damages. ${ }^{15}$

\footnotetext{
${ }^{13}$ Coney, Sahaja Yoga, 162-63.

${ }^{14}$ Known colloquially as the Hare Krishna movement or Hare Krishnas. The organization was founded in 1966 in New York by A. C. Bhaktivedanta Swami Prabhupada (1896-1977).

${ }^{15}$ Singer, Cults in Our Midst, 348-49.
} 
It happens that a cultic organisation conceals the details related to the actual identity of a facility, with the intent to avoid putting the parents and teachers off. This was the case of a private primary school in Poland, ${ }^{16}$ which for several years operated in one of the larger cities, and the owners of which, as it turned out later, were worshippers of a controversial Indian guru. They even employed a priest to teach religion classes, because most of the students came from Catholic families. After some time, it was disclosed that the facility was abusing the rights of parents to raise their children in the spirit they deem appropriate. There were also strange reactions from children after relaxation classes: they were sometimes drowsy and the more sensitive ones even lost touch with reality. They did not want to talk about what happened at school, and they sang bizarre songs. The phenomenon was exacerbated after the students went on extended 1-3-week school trips, during which their parents could not visit them. When the abuse was revealed, some parents, although it was in the middle of the school year, transferred their children to another place, where a class was created especially for them. Others remained with their children until the end of the year and moved them later. Several teachers left the school who apparently had absolutely no idea what ideology was promoted there. It should be added that the curriculum submitted to the educational authorities was not in line with the school curriculum. ${ }^{17}$

\section{ORGANISING HOME SCHOOLING}

In almost all countries of the world, education is compulsory for children in a certain age range, ${ }^{18}$ but in many of them school attendance is not compulsory as long as education is provided in a different form. This allows some cults to exclude their children from the general school system in order to protect them from (in their opinion) harmful influence of the external environment.

\footnotetext{
${ }^{16}$ Polish law provides for a possibility to establish non-public educational facilities, under Article 82 of the Act of 7 September 1991 on the Education System (Dz.U. of 1991, No. 95, item 425 as amended).

17 Ewa Miller-StefańSKA, "Sekty a prawo," in $A B C$ o sektach, ed. Mariusz Gajewski (Kraków: Civitas Christiana, 1999), 73-74.

${ }_{18}$ Article 14 of the International Covenant on Economic, Social and Cultural Rights (ICESCR) requires implementation, "within a reasonable number of years," the principle of compulsory education free of charge for all.
} 
For example, in France, Article 7 of the law on compulsory primary education dated 28 March $1882^{19}$ obliges parents to notify the mayor and the school inspector of the fact that their child is excluded from the school education. In such case the resources necessary to educate the child at home must be presented. The school district inspector should, after providing the information to the mayor, verify that these measures are legally acceptable. Teachers are not required to be qualified or have a diploma. The functioning of a private school is not subject to any restrictions in terms of timetable, programs and methods used. However, the restrictions apply to the standards of safety of premises, public order, sanitary conditions, social welfare, the morality of the principal and teaching staff. ${ }^{20}$

In a leaflet from November 1992, Tabitha's Place ${ }^{21}$ explain why they decided to settle down in France: "Like the believers of the first communities we have already mentioned, we have also encountered unexpected opposition. As it happens, in Germany, people are not entirely free to live according to their beliefs. As it had become clear, in order to maintain the atmosphere of love and order we had created, we had to educate our young children ourselves. We therefore developed a conscientious education programme which we believed would bring our children to a most suitable school level, while avoiding the very obvious problems that young children encounter in public schools today. The German government did not accept this alternative, as every child had to attend standard educational institutions. Our conscience refused to compromise, so we decided to leave the country. In France, the sound government still protects fundamental human rights. Having the government approved our home-based education programme for our children, we finally had the opportunity to follow what our consciences were telling us." 22

Also in The Family cult, ${ }^{23}$ homeschooling was widely practiced, and few children continued education after graduating high school. As it can be read in

\footnotetext{
${ }^{19}$ The law on compulsory primary education dated 28 March 1882 (Official Journal of the French Republic, 29 March 1882, no. 87, p. 1697-99). Amended on 22 May 1946 and 31 December 1985.

${ }^{20}$ Hayat El MounTACiR, Les enfants des sectes (Paris: Fayard, 1994), 196.

${ }^{21}$ The movement is a branch of an American group called The Twelve Tribes with seat in Hiddenite, NC, established by Elbert Eugene Spriggs (born in 1937).

${ }^{22}$ El MounTACIR, Les enfants des sectes, 197-198.

${ }^{23}$ Since 2004 the organization has been renamed to The Family International. Originally it was called The Children of God (1968-1977), later The Family of Love (1978-1981). It is usually referred to as The Family, the name formally used by them in the years 1982-2003.
} 
the organization's materials, its founder David Berg (1919-1994) "extolled the virtues of home education many years before the homeschooling movement became well known and accepted in many countries." ${ }^{24}$ However, it seems that the main reason for the positive attitude towards this form of education was the distrust of the outside world, defined by the Family members as The System. In the internal leaflet of the cult, Going home? Go mobile! we read: "But I certainly wouldn't send my kids to public school no matter what you do!" which is justified by a compilation of two Bible quotations: "Come out from among them \& be ye separate! Touch not the unclean thing that ye be not partakers of her sins \& judgements!" (2 Corinthians 6:17 and Revelation 18:4). It was further argued that many US states and many countries around the world allow home education of your own children. However, if this is not the case, cult members are advised to move. "In places where they're more liberal \& more free \& allow more freedom \& home schooling \& don't make you put your kids in school, well, fine, you may be able to settle down more," reads the material. ${ }^{25}$ While the cult says that home education is the best way to educate children, it is not the only way. "If the parents or the Home cannot supply an adequate education via home schooling, they may need to consider outside schooling, private tutoring, etc. It is not enough for a Home to supply the minimum school time if it does not result in an adequate education for the children," reads the leaflet titled Our children's education! ${ }^{26}$

An even more distinct expression of break-up with the cross-society values is the non-respecting of the compulsory education, illustrated by the example of the Polish Niebo (Heaven) cult from Majdan Kozłowiecki near Lubartów. ${ }^{27}$ Compulsory education is based directly on the Polish Constitution, ${ }^{28}$ and parents are-pursuant to Article 18 (1) of the Education Law-obliged, among others, to register their child at school and make sure that they go to school on a daily basis, unless they obtain a proper permit for the child to

\footnotetext{
${ }^{24}$ Peter, "The Family's History, Policies, and Beliefs Regarding Sex — Part 3," exFamily.org, 2007, ML \#3673, GN 1236, 10/07.

25 "Going Home? Go Mobile!" exFamily.org, 1998, DO 2507, 3/89, item 134.

${ }^{26}$ MARIA, “Our Children's Education!” exFamily.org, 1998, Maria \#343, DO 3066, 7/96, items $16-17$.

${ }^{27}$ A former religious community active in Poland established in 1990 in Majdan Kozłowiecki, led by Bogdan Kacmajor (born in 1954). At its peak the movement gathered 60 members.

28 "Everyone shall have the right to education. Education to 18 years of age shall be compulsory. The manner of fulfilment of schooling obligations shall be specified by statute" - Article 70 (1) of the Constitution of the Republic of Poland of 2 April 1997 (Journal of Laws of 1997, No. 78, item 483 as amended).
} 
fulfil their compulsory education outside of school. In the case of the aforementioned cult, none of these conditions was met. Its founder, Bogdan Kacmajor, claimed that school would do nothing for the children and that the issue of formal education would be better solved by "internal education" implemented in the church. He told a representative of the school authorities that no "this-world-law" contrary to their faith applies to them. ${ }^{29}$ His reaction to the idea of the compulsory education was violent. He did not want to send children to a school where "during a chemistry class they teach that you cannot change the particle composition." The members of the community who decided that they had pedagogical background, promoted "good attitudes" and artistic passion, such as painting or drawing, in the younger generation. ${ }^{30} \mathrm{In}$ 2001, the family of the cult leader was finally threatened by the court to be deprived of their parental rights and have their children placed in an institution if they did not start attending school. Then, Kacmajor's wife, Grażyna, begged the judge to suspend the decision, arguing that she would convince her husband to allow the children to begin formal education. So was the case and at the end of 2001, five children from Niebo, aged 8 to 14, started attending (albeit irregularly) the first grade of primary school in the village of Wandzin, near Majdan Kozłowiecki, making up almost half of the class of 12 pupils. ${ }^{31}$ After some time, Kacmajor's children were placed in a children's home in Kraśnik, located less than $70 \mathrm{~km}$ from the cult's residence, and a serious pedagogical problem arose as parents of local pupils started to protest. They were concerned about the age of the "heaven-kids," among whom the oldest one (sixteen-year-old) attended the second year of elementary school, and about "the principles that were instilled in them in the cult." The school management together with the mayor organized special meetings during which people were reassured, convinced and guaranteed that there was no reason to be afraid. The children finished school with very good result as they were amazingly gifted. They also turned out to be kind and friendly, and on their days off, the pupils' families were happy to host them in their homes. ${ }^{32}$

\footnotetext{
${ }^{29}$ Violetta KRASNOwSKA, "Wysłannik Boga. Sekta pod Lubartowem," Polityka (1993), no. 35: 14 .

${ }^{30}$ Mirosław Rewera, "Posłowie. Sekta Niebo i jej przywódca," in Sebastian Keller, Pięć lat w sekcie Niebo (Tychy: Maternus Media, 2011), 122.

31 Jerzy KowalczYK, "Nieba kres," Polityka (2005), no. 30: 34; Dariusz JĘDRYszKA, “Z Nieba do szkoły,” Dziennik Wschodni Lubelski (2002), no. 5: 1.

${ }^{32}$ KowalczyK, "Nieba kres," 34.
} 


\section{CONCLUSIONS}

The process of school adaptation of children from the Niebo cult can ultimately be assessed as quite successful, but in the case of other groups that - voluntarily or by obligation - open up to formal education, the course of events may look quite different. Children from such communities are sometimes ridiculed by their peers in the class, if only because of their strange outfits and peculiar habits. ${ }^{33}$ While adults may get some satisfaction from the idea of belonging to a group of "chosen" martyrs, still, the challenge may be difficult for the younger individuals, especially those forced into the role. For example, Mark Casey, who belonged to one of the Pentecostal communities as a child, spoke of his fears that someone he knew from school would one day come to the temple and witness their bizarre rituals. "I spent a lot of time worrying, terrified that some kid from my school would be invited as a visitor. I was always looking over my shoulder to see if someone was stupid enough to have brought a visitor. I was afraid I would be found out, because I knew our church wasn't like other kid's churches," recalls Casey. ${ }^{34}$

In the field of social sciences, we can distinguish "adaptive" and "marginalizing" religious organizations, depending on their attitude to the bonding of the believers with the mainstream culture and society. ${ }^{35}$ Representatives of the latter category of communities are often responsible for the break in the relationship between their own environment and the common school system, which is a consequence of either a complete exclusion of a group from the social environment, or of only partial isolation. For this purpose, as Hayat El Mountacir points out, the cults have assimilated appropriate laws to maintain control over the overall formation of their children. Common education (public or private) ensures the continuity of education and operates on a competitive basis. This is exactly what the cult rejects. It is interested not so much in the individuality of a child as in casting it in its own form. ${ }^{36}$

The already mentioned breakdown of a cult with the general social values, expressed in the limitation of its members' contact with people outside the cultic community, becomes the reason for the loss of both external and in-

\footnotetext{
${ }^{33}$ SINGER, Cults in Our Midst, 250.

34 Janet HeImLICH, Breaking Their Will: Shedding Light on Religious Child Maltreatment (Amherst: Prometheus Books, 2011), 155.

${ }^{35}$ James A. BeCKford, Cult Controversies: The Social Response to the New Religious Movements (London: Tavistock Publications, 1986), 99.

${ }^{36}$ El MounTACIR, Les enfants des sectes, 197.
} 
ternal control mechanisms aimed at limiting potential abuse. Amy Siskind regards it as "the key to understanding the distinctive challenge of preventing child abuse in totalist groups. ${ }^{\prime 37}$ The lack of these mechanisms makes children who remain within the structure of a cult more vulnerable than their peers who grow up in a society with control mechanisms, even if they are sometimes inadequately implemented. Thus, very little resources are left to detect possible exploitation. "Many children in these groups attend schools within their own communities, and physical or psychological problems which would often be detected by school authorities in the 'outside world' go unacknowledged or even undetected by community teachers and administrators," writes Siskind. ${ }^{38}$

On the other hand, children taught in the mainstream school system maintain regular contact with their peers from different families and social groups. Similarly, teachers and other employees of the education system are embedded in different social contexts, which allows them to get a perspective that lets them notice an occurring problem and, if necessary, offer help to the child. ${ }^{39}$ Therefore, it is important that the broadly understood school environment is not devoid of specialist knowledge in the field of cults and related phenomena. The solution here, as is usually the case, lies in adult pedagogy, which can often take place in parallel with primary prevention aimed at pupils. However, specialized training addressed to functionaries will also be necessary, with particular emphasis on school principals, but also to guidance counsellors, tutors, employees of psychological and pedagogical counselling centers, dormitory and boarding school employees, methodological advisers, school and community nurses.

\footnotetext{
${ }^{37}$ Amy SISKIND, "Child-Rearing Issues in Totalist Groups," in Misunderstanding Cults: Searching for Objectivity in a Controversial Field, ed. Benjamin Zablocki and Thomas Robbins (Toronto: University of Toronto Press, 2001), 443.

${ }^{38}$ Ibid. To avoid this problem, as Massimo Introvigne et al. argue, "it is certainly not unreasonable to reinforce controls and inspections, which is different from eliminating homeschooling altogether"; see Massimo InTrovigne, et al., "Separatism," Religion, and "Cults": Religious Liberty Issues ([Paris]: n. p., 2020), 8.

${ }^{39}$ The attention is drawn to the possible forms of intervention in such cases by Mariusz GAJEwSKI, "Młodzież a współczesne kontrowersyjne sekty: wybrane zagadnienia," Homo et Societas: wokót pracy socjalnej, no. 3 (2018): 44.
} 


\section{BIBLIOGRAPHY}

Act of 7 September 1991 on the Education System. Dz.U. [Polish Journal of Laws] of 1991, No. 95, item 425 as amended.

BeCKford, James A. Cult Controversies: The Social Response to the New Religious Movements. London: Tavistock Publications, 1986.

Coney, Judith. Sahaja Yoga: Socializing Processes in a South Asian New Religious Movement. Richmond: Curzon Press, 1999.

Constitution of the Republic of Poland of 2 April 1997. Dz.U. [Polish Journal of Laws] of 1997, No. 78, item 483 as amended.

El MounTACIR, Hayat. Les enfants des sectes. Paris: Fayard, 1994.

GAJEwSKI, Mariusz. "Młodzież a współczesne kontrowersyjne sekty: wybrane zagadnienia." Homo et Societas: wokót pracy socjalnej, no. 3 (2018): 36-47.

"Going Home? Go Mobile!” exFamily.org, 1998. DO 2507, 3/89.

Hassan, Steven. Combating Cult Mind Control. Newton: Freedom of Mind Press, 2018.

HeImLich, Janet. Breaking Their Will: Shedding Light on Religious Child Maltreatment. Amherst: Prometheus Books, 2011.

International Covenant on Economic, Social and Cultural Rights. Adopted and opened for signature, ratification and accession by General Assembly resolution 2200A (XXI) of 16 December 1966 entry into force 3 January 1976, in accordance with article 27.

Introvigne, Massimo, Alessandro Amicarelli, Willy Fautré, Bernadette Rigal-Cellard, and Frédéric-Jérôme PANSIER. "Separatism," Religion, and "Cults": Religious Liberty Issues. White paper published online by Centre for Studies on New Religions, 2020. Accessed January 18, 2021. https://www.cesnur.org/2020/separatism-religion-and-cults.htm.

JęDryszKa, Dariusz. "Z Nieba do szkoły.” Dziennik Wschodni Lubelski, January 7, 2002. https://www.dziennikwschodni.pl/lublin/z-nieba-do-szkoly,n,1000020271.html.

KowalczyK, Jerzy. "Nieba kres." Polityka, July 30, 2005, pp. 32-34. https://www.polityka. pl/archiwumpolityki/1864764,1,nieba-kres.read.

KrasnowsKA, Violetta. “Wysłannik Boga. Sekta pod Lubartowem.” Polityka, August 8, 1993, p. 14.

Kropveld, Michael, and Marie-Andrée Pelland. The Cult Phenomenon: How Groups Function. Translated by Natasha DeCruz and Gwendolyn Schulman. [Montreal]: Info-Cult, 2006.

LALICH, Janja, and Madeleine ToBIAS. Take Back Your Life: Recovering from Cults and Abusive Relationships. Berkeley: Bay Tree Publishing, 2006.

Law on compulsory primary education dated 28 March 1882. Official Journal of the French Republic, 29 March 1882, no. 87, p. 1697-99.

MARIA. "Our Children's Education!” exFamily.org, (1998): Maria \#343, DO 3066, 7/96.

Miller-STEFAŃSKA, Ewa. "Sekty a prawo." In $A B C$ o sektach, edited by Mariusz Gajewski, 71-80. Kraków: Civitas Christiana, 1999.

NowAKOWSKI, Piotr T. "Uzasadnienie ujęcia problemu sekt na gruncie pedagogiki resocjalizacyjnej." In Sekty jako problem współczesności, edited by Piotr T. Nowakowski, 183-92. Mysłowice: Górnośląska Wyższa Szkoła Pedagogiczna imienia Kardynała Augusta Hlonda, 2008.

NowAKOwSKI, Piotr T. Sekty: co każdy powinien wiedzieć. Tychy: Maternus Media, 1999. 
PALAyon, Raymund T., Richard Watson TodD, and Sompatu Vungthong. "The Language of Destructive Cults: Keyness Analyses of Sermons." Communication \& Language at Work 7, no. 1 (2020): 42-58.

Peter. "The Family's History, Policies, and Beliefs Regarding Sex — Part 3." exFamily.org, (2007): ML \#3673, GN 1236, 10/07.

PTASZEK, Robert T. "Filozoficzno-kulturowe uwarunkowania działalności współczesnych grup kultowych.” In Grupy kultowe: uwarunkowania społeczne, edited by Mariusz Gajewski, 409-27. Kraków: WAM, 2012.

Rewera, Mirosław. "Posłowie. Sekta Niebo i jej przywódca." In Sebastian Keller, Pięć lat w sekcie Niebo, 115-30. Tychy: Maternus Media, 2011.

Singer, Margaret T. Cults in our midst. San Francisco: Jossey-Bass Publishers, 2003.

SISKIND, Amy. "Child-Rearing Issues in Totalist Groups." In Misunderstanding cults: searching for objectivity in a controversial field, edited by Benjamin Zablocki and Thomas Robbins, 415-51. Toronto: University of Toronto Press, 2001.

SYNEK, Eva M. "The Limits of Religious Tolerance - A European Perspective." Journal for the Study of Religions and Ideologies 1, no. 3 (2002): 39-51.

U.K. Department for Children, Schools And Families. Elective Home Education: Guidelines for Local Authorities. London, 2007.

WIĘCKIEWICZ, Bogdan. "Rodzice i szkoła wobec edukacji dzieci w wieku sześciu lat." In Rodzina polska - nowe wyzwania. Wybrane aspekty, edited by Bogdan Więckiewicz, 14-50. Stalowa Wola: Wydział Zamiejscowy Nauk o Społeczeństwie KUL w Stalowej Woli, 2013.

\section{CRACKS IN EDUCATION: ALTERNATIVE SCHOOLING IN CULTIC GROUPS}

\section{Summary}

The breakdown of cross-social values characteristic in a cult, expressed in limiting its members' contacts with people from outside their own community, manifests itself in its critical attitude towards the common education system, and therefore in establishing its own schools, with a formula of education that is different from that found in traditional educational institutions. Some groups also use legal provisions enabling the implementation of home education, which allows them to protect children against the harmful, in their opinion, impact of the external environment. All this leads to a kind of gap in the cult's relationship with the education system, causing it to lose both external and internal control mechanisms to limit potential abuse, making children from cultic milieu more vulnerable and defenseless than their peers growing up in a society equipped with the mentioned mechanisms, even if they are sometimes insufficiently implemented. Pupils taught in the mainstream school system maintain regular contact with their peers from different families and social groups. Similarly, teachers and other employees of the education system are embedded in different social contexts, which provides them with a perspective that lets them notice an occurring problem and offer help to the child.

Keywords: cultic groups; education system; alternative schooling; home schooling. 


\title{
EDUKACYJNE PĘKNIĘCIE: O KSZTAŁCENIU ALTERNATYWNYM W GRUPACH KULTOWYCH
}

\author{
Streszczenie
}

Cechujący sektę rozbrat z wartościami ogólnospołecznymi, wyrażający się w ograniczaniu kontaktów jej członków z osobami spoza własnego środowiska, przejawia się w jej krytycznym stosunku do powszechnego systemu szkolnego, a w związku z tym - w powoływaniu własnych szkół, gdzie obowiązuje formuła kształcenia odmienna od spotykanej w tradycyjnych instytucjach oświatowych. Niektóre ugrupowania wykorzystują też zapisy prawne umożliwiające realizowanie nauczania domowego, co pozwala im uchronić dzieci przed - szkodliwym w ich mniemaniu - wpływem środowiska zewnętrznego. Wszystko to prowadzi do swoistego pęknięcia w relacjach sekty z systemem oświaty, będąc przyczyną utraty przez nią tak zewnętrznych, jak i wewnętrznych mechanizmów kontroli służących ograniczaniu potencjalnych nadużyć, przez co dzieci ze środowisk kultowych stają się bardziej bezbronne aniżeli rówieśnicy wzrastający w społeczeństwie wyposażonym we wspomniane mechanizmy, nawet jeśli są one czasem implementowane w sposób niezadowalający. Uczniowie odbywający naukę w ramach powszechnego systemu szkolnego utrzymują regularny kontakt $\mathrm{z}$ rówieśnikami pochodzącymi z różnych rodzin i grup społecznych. Podobnie w odmiennych kontekstach społecznych osadzeni są nauczyciele i pozostali pracownicy oświaty, co daje im pespektywę umożliwiającą dostrzeżenie potencjalnego problemu i pospieszenie dziecku z pomocą.

Słowa kluczowe: grupy kultowe; system oświaty; kształcenie alternatywne; nauczanie domowe. 